\section{Relationship between peak expiratory flow and impaired functional capacity in obese individuals}

\author{
Relação entre o pico de fluxo \\ expiratório e o prejuízo da \\ capacidade funcional em obesos
}

\author{
Graziele Mayra Santos Moreira (iD ${ }^{1 *}$ \\ Angela Maria Ribeiro (1) ${ }^{2}$ \\ Patrícia Maria de Melo Carvalho (iD ${ }^{2}$ \\ Pedro Augusto de Carvalho Mira $\mathbb{1}^{3}$ \\ Isabelle Magalhães Guedes Freitas (10 ${ }^{4}$

\footnotetext{
1 Universidade Federal de São João del-Rei (UFSJ), São João del Rei, MG, Brazil

${ }^{2}$ Universidade Presidente Antonio Carlos (UNIPAC), Barbacena, MG, Brazil

${ }^{3}$ Universidade Federal Fluminense (UFF), Niteroi, RJ, Brazil

${ }^{4}$ Faculdade de Ciências Médicas e da Saúde (SUPREMA), Juiz de Fora, MG, Brazil
}

Date of first submission: June 25, 2020

Last received: October 21, 2020

Accepted: November 30, 2020

Associate editor: Janice Luisa Lukrafka Tartari

*Correspondence: grazmayra@gmail.com

\section{Abstract}

Introduction: Obesity, characterized by the accumulation of excess body fat, can alter respiratory mechanics and compromise functional capacity. Given its increasing prevalence and the significant morbidity associated with the condition, it is important to investigate techniques that enable rapid, easy measurement of lung function and the possible correlation between obesity and functional capacity. Objective: To assess lung function and functional capacity in obese adults and determine whether there is a correlation between reduced peak expiratory flow and impaired functional capacity. Methods: 30 participants, distributed into two groups: obese ( $36 \pm 13$ years) and normal weight ( $31 \pm 9$ years) were evaluated based on anthropometric measurements, the six-minute walk test (6MWT) and peak expiratory flow (PEF). Results: The obese individuals showed reduced PEF (382 \pm 99 vs. $497 \pm 104 \mathrm{~L} / \mathrm{min}, \mathrm{p}<0.01)$, walked shorter distances in the $6 \mathrm{MWT}(453 \pm 37$ vs. $617 \pm 50 \mathrm{~m}$, $p<0.01$ ), had higher blood pressure and perceived exertion $(p<0.05)$ when compared to normal weight participants. Additionally, there was a positive significant association between expiratory flow and distance walked in the 6MWT ( $r=0.635$ and $p<0.001)$. Conclusion: Obese individuals exhibited lower PEF and walked shorter distances in the 6MWT, indicating a positive correlation between these two variables. In light of this outcome, the assessment methods used could contribute to improving analysis of respiratory and functional status in this population and aid in exercise prescription.

Keywords: Obesity. Peak expiratory flow. Walk test. Rapid assessment. 


\section{Resumo}

Introdução: A obesidade, caracterizada por acúmulo excessivo de tecido adiposo no organismo, pode alterar a mecânica ventilatória trazendo prejuízos funcionais. Considerando a prevalência crescente da obesidade, bem como a grande morbidade associada a esta condição, torna-se relevante investigar técnicas de mensuração rápidas e fáceis da função ventilatória e a possível correlação com a capacidade funcional.

Objetivo: Avaliar a função ventilatória e a capacidade funcional em adultos obesos e determinar se pico de fluxo expiratório reduzido está correlacionado com prejuízo da capacidade funcional. Métodos: 30 participantes, distribuídos em dois grupos: obeso (36 \pm 13 anos) e eutrófico (31 \pm 9 anos) foram avaliados por meio de medidas antropométricas, do teste de caminhada de seis minutos (TC6') e da avaliação do pico de fluxo expiratório (PFE). Resultados: Os indivíduos obesos apresentaram reduzido PFE (382 \pm 99 vs. $497 \pm 104 \mathrm{~L} / \mathrm{min}, p$ $<0,01)$ e percorreram menor distância no TC6' (453 \pm 37 vs. $617 \pm 50 m, p<0,01)$ com maior pressão arterial e percepção de esforço $(p<0,05)$ quando comparados aos eutróficos. Além disso, foi encontrada correlação positiva e significativa entre fluxo expiratório e distância percorrida $(r=0,635$ e $p<0,001)$.

Conclusão: Os indivíduos obesos tiveram menor PFE e menor distância percorrida no TC6', constatada correlação positiva entre essas duas variáveis. Diante de tal desfecho, a inclusão dos métodos avaliativos utilizados podem contribuir para melhor análise da condição respiratória e funcional dessa população e auxiliar na prescrição de exercícios.

Palavras-chave: Obesidade. Pico do fluxo expiratório. Teste de caminhada. Avaliação rápida.

\section{Introduction}

Obesity, a chronic condition characterized by the accumulation of excess body fat, is a major global public health problem., ${ }^{1,2}$ The World Health Organization (WHO) estimates that one billion people worldwide are overweight and 300 million of these are obese.Projections are that $40 \%$ of the population in the USA, $30 \%$ in England and $20 \%$ in Brazil will be obese by $2025 .^{3}$

Different anthropometric indices can be used to identify obesity. The body mass index (BMI) is considered the international standard for obesity classification, while the abdominal circumference (AC) and waist-hip ratio (WHR) characterize increased cardiovascular risk. ${ }^{4}$ According to the $\mathrm{WHO}$, individuals with $\mathrm{BMI}$ between 18.5 and $24.9 \mathrm{~kg} / \mathrm{m}^{2}$ are considered normal weight and those with values above $30 \mathrm{~kg} / \mathrm{m}^{2}$ are considered obese. ${ }^{5}$ For $A C$ and WHR, respective measures for men and women of more than 102 and $88 \mathrm{~cm}$ and 0.95 and

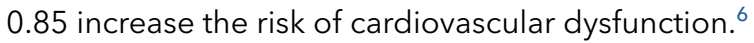

Studies show that obesity can compromise respiratory system mechanics. ${ }^{7}$ Obese adults tend to experience respiratory problems, with reduced aerobic capacity and lung compliance as well as increased airway resistance, leading to a decline in functional residual capacity (FRC), forced vital capacity (FVC), residual volume (RV) and forced expiratory volume in one second $\left.\left(\mathrm{FEV}_{1}\right) \cdot\right)^{8,9}$

Changes in respiratory function can be identified using a peak flow meter, which evaluates peak expiratory flow (PEF), that is, the maximum flow generated during a forced expiration. ${ }^{10}$ This is a simple, non-invasive, lowcost technique that exhibits good reliability because of its high correlation with $\mathrm{FEV}_{1}$, determined by conventional spirometry. ${ }^{11}$

In addition to altering respiratory function, increased body weight also has systemic repercussions that cause intolerance to physical exercise and, when combined with sedentarism, contribute to reducing physical and functional capacity. ${ }^{12}$ In this respect, it is important to underscore the applicability of the six-minute walk test (6MWT) in assessing functional capacity. This simple practical method evaluates the responses of all the systems involved in the test, including the respiratory, cardiovascular and muscular systems. ${ }^{13,14}$

The literature indicates that obese individuals show altered physical and respiratory function, with reduced lung volumes and capacities detected by spirometry and shorter distances walked in the 6MWT. ${ }^{15}$ However, despite the effectiveness of assessing ventilatory function based on PEF using a peak flow meter, research on this approach is scarce, especially in obese individuals.Moreover, the global increase in obesity and associated complications as well as the specificity and low cost of the 6MWT in evaluating the physical and functional status of this population justify the present study, which aims to assess the lung function and functional capacity of obese individuals and determine whether there is a correlation between reduced PEF and impaired functional capacity. 


\section{Methods}

The protocol of the present study was approved by the Research Ethics Committee of President Antônio Carlos University (UNIPAC), under process no. $1462961 / 2016$, and followed the ethical principles of the Declaration of Helsinki. All the participants who agreed to take part provided written informed consent.

\section{Participants}

Convenience sampling was used and participation was free of charge. The sample consisted of 30 sedentary participants of both sexes, aged between 20 and 59 years, divided into two groups: the obese group, containing 15 individuals with $\mathrm{BMI} \geq 30 \mathrm{~kg} / \mathrm{m}^{2}$, and normal weight group, with 15 individuals whose BMI was between 18.5 and $24.9 \mathrm{~kg} / \mathrm{m}^{2}$. Physically active individuals, those with cognitive and physical disorders, smokers and drug addicts, people who did not agree with the proposed procedure or exhibited decompensated respiratory and/ or cardiac and metabolic comorbidities contraindicated for the procedures according to the recommended protocols were excluded from the study. ${ }^{16}$

\section{Procedures}

First, anamnesis was performed, including a description of personal information, medical history and lifestyle habits, vital signs assessment and anthropometric measurements.

Lung function was assessed by analyzing PEF, using a portable peak flowmeter with a numbered scale and red marker that indicates the result in L/min, as well as individual disposable peak flow mouthpieces and Speedo ${ }^{\circledR}$ nose clips to prevent air from escaping. Peak expiratory flow was measured with participants sitting on an armless chair, with their head in a neutral position, left hand resting on the anterior thigh and right hand holding the device. Forced expiration was performed from full lung inflation to total lung capacity. The maneuver was executed at least three times, computing the highest value obtained. The PEF values obtained were compared against those predicted in the table compiled by Leiner et al., ${ }^{17}$ which considers the height and weight of participants.

Functional capacity was evaluated using the 6MWT, in accordance with the American Thoracic Society (ATS).
The test was conducted on a 30-meter-long flat, hard covered surface, with every meter marked and a cone at either end of the walkway. Participants were instructed to walk for six minutes from one end to the other as fast as possible, without running, and standardized encouragements such as "you only have a few minutes left" and "you are doing well" were given every minute. After the 6MWT, the predicted distance was calculated using the equation proposed by Enright and Sherrill, ${ }^{18}$ and the distance walked based on the markings indicating the number of laps performed.Additionally, heart rate $(H R)$ and oxygen saturation $\left(\mathrm{S}_{\mathrm{a}} \mathrm{O}_{2}\right)$, the latter measured with a Pulso Moriya ${ }^{\circledR}$ oximeter, were determined after a 5-minute rest with participants seated, every minute during the test and after its completion. Blood pressure (BP) was measured with a $\mathrm{Bic}^{\circledR}$ mercury sphygmomanometer and respiratory rate (RR) by observing chest expansion at the beginning of the 6MWT, while participants were resting, and after the test. Perceived exertion was assessed from 0 to 10 using a modified Berg scale and the results obtained were compared pre-test, in the third minute of the 6MWT, and after completion.

\section{Data analysis}

Data distribution was analyzed by the ShapiroWilk test. After testing for normality, descriptive and inferential analyses were represented by mean \pm standard deviation or absolute frequency (for the variable sex). For possible intergroup differences in the physical, hemodynamic, lung function and functional capacity characteristics investigated, the Student's t-test was used for variables with normal distribution and the Mann-Whitney $U$ test for non-normal distribution. The sex ratio of the study population was analyzed by the chi-squared test.

Possible differences between predicted and measured values were analyzed by the student's t-test (dependent samples).

Pearson's correlation was applied to assess the association between PEF and distance walked in the 6MWT. Two-way repeated measures ANOVA was used to evaluate possible behavioral differences for all the variables measured during the 6MWT. Significance was set at $p<0.05$ for all the statistical tests and the analyses were performed using statistical software (STATISTICA 8.0, StatSoft Inc., USA). 


\section{Results}

The results obtained indicate similar age, height and sex ratio between the groups. However, as expected, anthropometric variables, weight, BMI, AC, WC, HC and WHR differed significantly between groups, with higher values recorded in obese individuals (Table 1).

With respect to predicted PEF, scores in the normal weight group were within the predicted range, whereas obese individuals obtained low values (p1). The obese group obtained significantly lower PEF scores than their normal weight counterparts (p2) (Table 2).

The obese group performed worse in the 6MWT, walking shorter distances than the normal weight participants. These results are presented in Table 3.

The behavior of cardiorespiratory variables differed between groups during the 6MWT, as shown in Figure 1. The obese participants obtained significantly higher systolic (SBP) and diastolic blood pressure (DBP) readings at both moments of the test (group effect: SBP $p=0.002$; DBP $\mathrm{p}<0.001)$, and significant increases after the test (time effect: SBP $p<0.001$; DBP $p=0.045$ ). Heart rate and $\mathrm{S}_{\mathrm{a}} \mathrm{O}_{2}$ were similar between the groups (group effect $H R: p=0.14 ; \mathrm{S}_{\mathrm{a}} \mathrm{O}_{2} \mathrm{p}=0.511$ ); however, $\mathrm{HR}$ increased (time effect: $\mathrm{p}<0.001$ ) and $\mathrm{S}_{\mathrm{a}} \mathrm{O}_{2}$ declined (time effect: $p=0.042$ ) at the start of the test.

Respiratory rate and Borg scale scores differed between groups (group effect: HR p $<0.001$; Borg $p=0.044)$, with higher values recorded for obese participants. Additionally, the data show that the 6MWT raised RR and Borg scale values (time effect: $p<0.001$ ); these physiologically expected responses are shown in Figure 1.

Indeed, a positive significant correlation was observed between PEF and distance walked in the 6MWT $(r=0.635$ and $p<0.001)$, as shown in Figure 2 .

Table 1 - Physical and anthropometric characteristics of the obese and normal weight groups

\begin{tabular}{lccc}
\hline & $\begin{array}{c}\text { Normal weight } \\
(\mathbf{n}=\mathbf{1 5})\end{array}$ & $\begin{array}{c}\text { Obese } \\
(\mathbf{n}=\mathbf{1 5})\end{array}$ & $\mathbf{p}$ \\
\hline Age (years) & $30.66 \pm 8.98$ & $36.40 \pm 12.67$ & 0.232 \\
Sex (M/F) & $10 / 5$ & $10 / 5$ & 0.100 \\
Height $(\mathrm{cm})$ & $1.64 \pm 0.07$ & $1.67 \pm 0.08$ & 0.390 \\
Weight $(\mathrm{kg})$ & $61.45 \pm 9.67$ & $103.52 \pm 27.90$ & $<0.001$ \\
BMl $\left(\mathrm{kg} / \mathrm{m}^{2}\right)$ & $22.54 \pm 2.07$ & $36.77 \pm 7.50$ & $<0.001$ \\
AC $(\mathrm{cm})$ & $80.20 \pm 6.92$ & $119.2 \pm 20.96$ & $<0.001$ \\
WC $(\mathrm{cm})$ & $73.86 \pm 8.94$ & $106.33 \pm 16.23$ & $<0.001$ \\
HC $(\mathrm{cm})$ & $95.93 \pm 4.23$ & $119.80 \pm 13.30$ & $<0.001$ \\
WHR & $0.76 \pm 0.07$ & $0.88 \pm 0.10$ & $<0.001$ \\
\hline
\end{tabular}

Note: $\mathrm{M}=$ male; $\mathrm{F}=$ Female; $\mathrm{BMI}=$ body mass index; $\mathrm{AC}=$ abdominal circumference; $W C=$ waist circumference; $H C=$ hip circumference; WHR: waist hip ratio.

Table 2 - Predicted and measured peak expiratory flow (PFE) in the obese and normal weight groups

\begin{tabular}{lccc}
\hline & Normal weight & Obese & p2 \\
\hline Predicted PFE (L/min) & $473.73 \pm 78.33$ & $474.93 \pm 86.43$ & 0.968 \\
Measured PFE (L/min) & $497.33 \pm 104.02$ & $382 \pm 99.08$ & 0.004 \\
p1 & 0.138 & 0.001 & - \\
\hline
\end{tabular}

Note: $p 1$ = intragroup; $p 2$ = intergroup.

Table 3 - Distance walked in the six-minute walk test for the normal weight and obese groups

\begin{tabular}{lccc}
\hline & Normal weight & Obese & p2 \\
\hline Predicted distance $(m)$ & $562.09 \pm 52.13$ & $455.72 \pm 91.25$ \\
Distance walked $(\mathrm{m})$ & $616.86 \pm 50.23$ & $453.26 \pm 37.44$ \\
p1 & 0.002 & 0.001 & $<0.001$ \\
\hline
\end{tabular}

Note: $\mathrm{p} 1$ = intragroup; $\mathrm{p} 2$ = intergroup. 

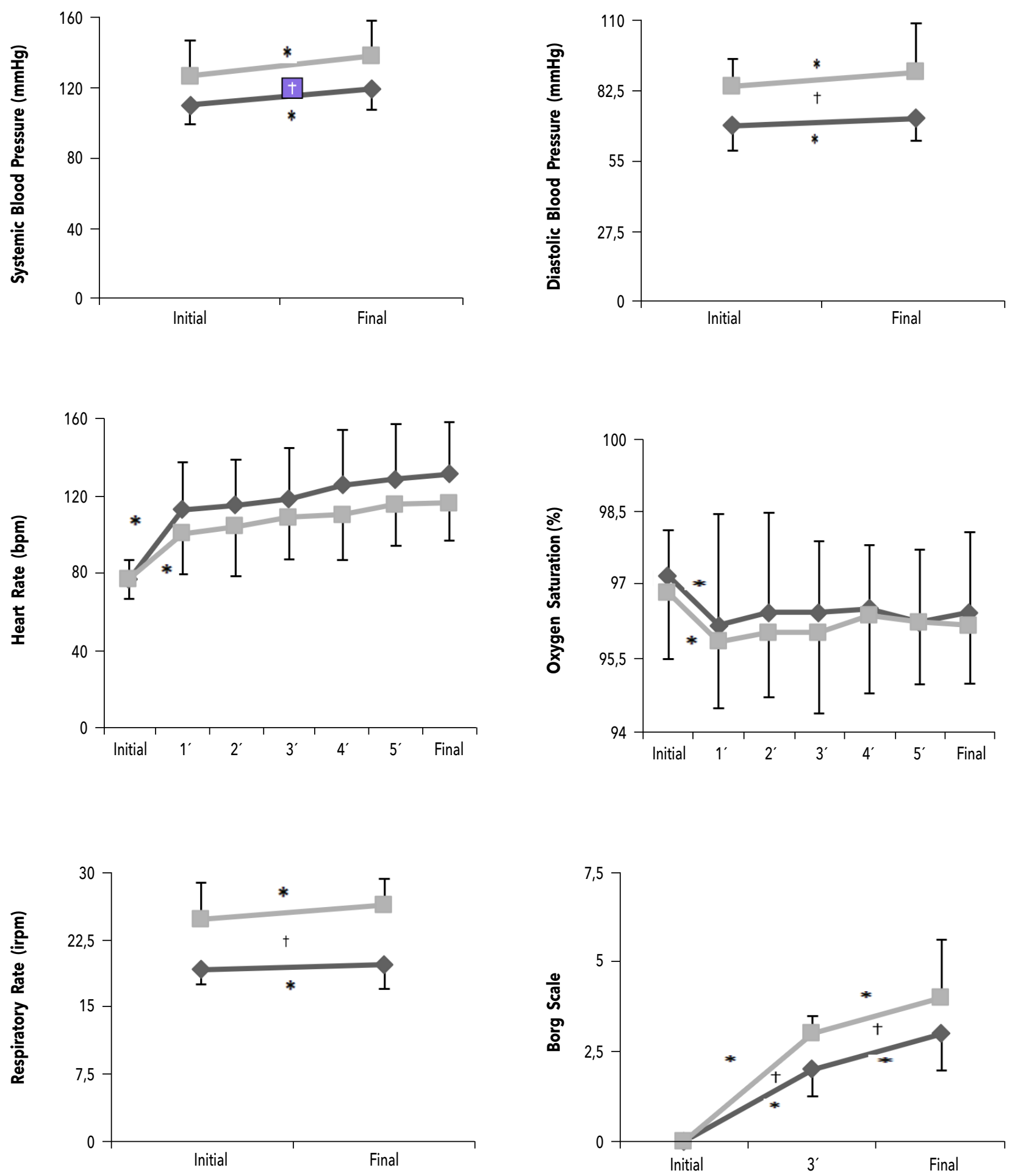

Figure 1 - Systolic blood pressure, diastolic blood pressure, heart rate, oxygen saturation, respiratory rate, borg scale cores in the six-minute walk test. ${ }^{*}=$ Significant time difference between consecutive moments $(p<0.05)$. $t$ Significant group difference $(p<0.05) . \multimap$ Normal weight - Obese 


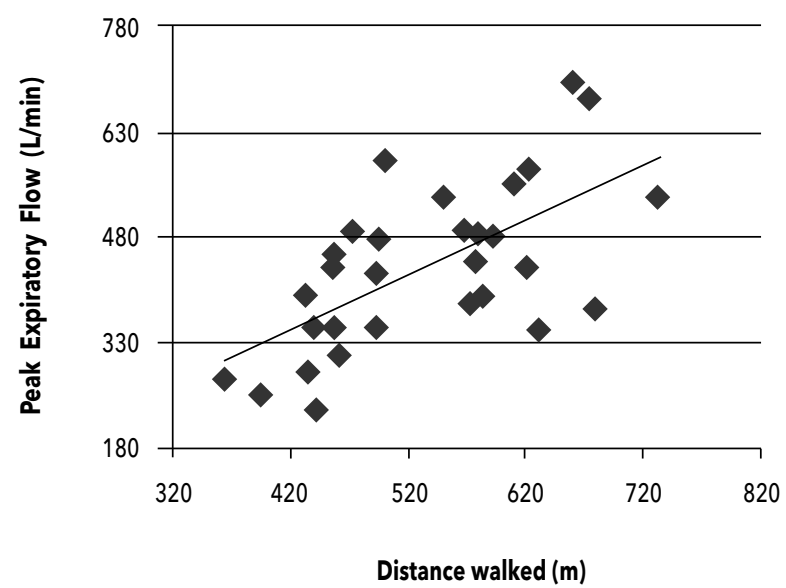

Figure 2 - Correlation between peak expiratory flow and distance walked in the six-minute walk test based on mean \pm standard deviation $(r=0.635$ and $p<0.001)$.

\section{Discussion}

The main finding of the present study is that obese adults exhibit compromised lung function, characterized by lower forced expiratory flow, and that this impairment is associated with reduced functional capacity. This relationship can be justified by the fact that obese participants exhibited higher BP as a cardiovascular effect, as well as signs of exhaustion, with high RR and perceived exertion results in pre- and post-test comparisons. ${ }^{19}$

Previous studies demonstrated that obesity negatively affects lung function, resulting in reduced FVC, FEV 1 and PEF. ${ }^{20,21}$ These findings were corroborated in the present study, with obese participants obtaining lower PEF values than their normal weight counterparts. Similarly, Gundogdu and Eryilmaz ${ }^{22}$ assessed 1,439 obese and normal weight children and adolescents and found a negative association between BMI and PEF. Al Ghobain ${ }^{23}$ observed a decline in PEF in obese individuals (479 \pm 95.62) when compared to non-obese ones (508.42 \pm 113.65), but no significant difference in $\mathrm{FEV}_{1}, \mathrm{FVC}$, and $\mathrm{FEV}_{1} / \mathrm{FVC}$. On the other hand, Alves et al. ${ }^{24}$ compared PEF in non-smokers obese individuals, smokers, and healthy non-smokers, and found better expiratory flow in obese participants. However, the fact that physically active individuals and adults of both sexes were included may have contributed to these results.

In regard to the 6MWT, our results indicate a significant intergroup difference in distance walked, with obese individuals exhibiting worse performance. Corroborating these findings, Retory et al. ${ }^{25}$ also found that obese adults walked shorter distances in the 6MWT. Bautista et al. ${ }^{26}$ reported that obese participants walked approximately 100 meters less than their normal weight counterparts. Even among the severely obese, Santarém et al. ${ }^{27}$ reported that individuals with a BMI between 40 and $49.9 \mathrm{~kg} / \mathrm{m}^{2}$ walked further than those who BMI was 50 to $60 \mathrm{~kg} / \mathrm{m}^{2}$.

Although poor lung function can compromise functional capacity, obese individuals do not always exhibit reduced lung volumes and capacities. ${ }^{23}$ Gontijo et al. ${ }^{28}$ found that $90.3 \%$ of participants showed normal spirometry, but analysis of the association with the 6MWT indicated a positive correlation, that is, individuals with higher pre- and post-bronchodilator FEV $/$ /FVC and PEF values walked further. The bronchodilator response was not used in PEF analysis in the present study, but a positive correlation was observed between PEF and distance walked in the 6MWT.

In regard to SBP, DBP, HR, RR and perceived exertion, values in both groups increased from pre- to posttest. Likewise, Manzano et al. ${ }^{29}$ observed a significant increase in SBP, HR, RR and perceived exertion after the 6MWT. This is because the greater metabolic demands triggered by the 6MWT lead to hemodynamic adaptation and influence the cardiovascular system. Increased SBP and HR are directly related, since a rise in the latter alters cardiac output. Respiratory rate and perceived exertion increase due to the rise in oxygen consumption and carbon dioxide production, resulting in greater pulmonary ventilation and dyspnea. ${ }^{30,31}$

With respect to these cardiovascular variables, analyzed during the 6MWT, the positive pressure and chronotropic response can be justified by sympathetic activation. Trevizani et al. ${ }^{32}$ found that HR tends to increase linearly with exertion and that $\mathrm{SaO}_{2}$ remains unchanged when the oxygen supply to the body is satisfactory, however, $\mathrm{SaO}_{2}$ declined in the present study. In this context, Retory et al. ${ }^{25}$ reported that obese individuals displayed a higher rate of dyspnea during the 6MWT. This result is similar to that of the present study, whereby perceived exertion was greater among the obese participants.

Sympathetic activation may be hyperactive in cardiometabolic diseases due to the respiratory muscle metaboreflex. In these cases, prioritized perfusion to ventilatory muscles such as the diaphragm could explain 
the lower blood supply to peripheral muscles, resulting in less tolerance to physical exercise and greater pressure levels in obese individuals. ${ }^{25}$ In this regard, obese adults experienced greater lower limb fatigue in the 6MWT, low breathing reserve and increased dyspnea during exertion, likely explaining the positive correlation observed between distance walked in the 6MWT and PEF. ${ }^{28}$

The fact that gold standard methods such as spirometry and the cardiopulmonary exercise test were not used in the present study could be questioned. However, it is important to underscore that the peak flow meter and 6MWT are validated and recommended by the ATS, widely used in clinical practice and exhibit good reliability and scientific relevance for the proposed objective. ${ }^{18-33}$

A limitation of this study was the fact that, although results were obtained for the population in question, the sample size was small. Another important limitation was the failure to assess responses of the autonomic cardiac and vascular nervous systems, since the objective was not to investigate the mechanisms responsible for the limitation to physical exercise. As such, further research should be conducted to clarify this information.

\section{Conclusion}

Obese individuals exhibited reduced peak expiratory flow and walked shorter distances in the sixminute walk test. Low peak expiratory flow is directly correlated with decreased functional capacity. In light of this outcome, the assessment methods used could contribute to improving analysis of respiratory and functional status in this population and aid in exercise prescription. The results support an easy-to-perform assessment of the health status of obese individuals that could suggest, at least in part, greater risk of morbidity.

\section{Author's contributions}

GMSM and AMR participated in all stages of the study, from its conception to writing the manuscript, and were responsible for choosing the topic, planning and carrying out the research, data collection in the field, as well as data analysis and interpretation.

PMMC provided support in study planning, revised data interpretation and corroborated in writing the manuscript. PACM assisted in the statistical design, revised data analysis and interpretation and corroborated in writing the manuscript. IMGF was the study advisor, responsible for guiding the research and the statistical design, assisted in defining the topic and methods used for respiratory and functional assessment, monitored data collection in the field, performed data analysis and interpretation, reviewed the reports and corroborated in writing the manuscript.

All the authors contributed to compiling the manuscript.

\section{References}

1. Zheng Y, Manson JE, Yuan C, Liang MH, Grodstein F, Stampfer $\mathrm{MJ}$, et al. Associations of weight gain from early to middle adulthood with major health outcomes later in life. JAMA. 2017;318(3):255-69. DOI

2. Kim MK, Heo Y. Metabolic surgery in korea: what to consider before surgery. Endocrinol Metab (Seoul). 2017;32(3):307-15. DOI

3. Conde $\mathrm{WL}$, Borges C. $O$ risco de incidência e persistência da obesidade entre adultos brasileiros segundo seu estado nutricional ao final da adolescência. Rev Bras Epidemiol. 2011;14(Supl 1):71-9. DOI

4. Quesada K, Detregiachi CRP, Barbalho SM, Oliveira MRM, Rasera I, Vaz EC, et al. Perfil socioeconômico e antropométrico de candidatas à cirurgia bariátrica pelo sistema único de saúde. Saude Pesqui. 2015;8(3):431-8. Full text link

5. Oliveira CC, Costa ED, Roriz AKC, Ramos LB, Gomes Neto M. Preditores de síndrome metabólica em idosos: uma revisão. Int J Cardiovasc Sci. 2017;30(4):343-53. Full text link

6. Malshe SD, Udipi SA. Waist-to-height ratio in Indian women: comparison with traditional indices of obesity, association with inflammatory biomarkers and lipid profile. Asia Pac J Public Health. 2017;29(5):411-21. DOI

7. Dixon $A E$, Peters $U$. The effect of obesity on lung function. Expert Rev Respir Med. 2018;12(9):755-67. DOI

8. Aguiar IC, Reis IS, Freitas Jr WR, Malheiros CA, Laurino Neto RM, Oliveira LVF. Estudo do sono e função pulmonar em pacientes obesos mórbidos. Fisioter Mov. 2012;25(4):831-8.DOI 
9. Scipioni G, Cieslak F, Rosário Filho NA, Leite N. Função pulmonar de obesos mórbidos submetidos à cirurgia bariátrica. Fisioter Mov. 2011;24(4):621-7. DOI

10. Oliveira e Silva L, Silva PL, Nogueira AMOC, Silva MB, Luz GCP, Narciso FV, et al. Avaliação do broncoespasmo induzido pelo exercício avaliado pelo Peak Flow Meter em adolescentes obesos. Rev Bras Med Esporte. 2011;17(6):393-6. DOI

11. Matteoni SPC, Beuno Jr CR, Teixeira LR. Efeito de um programa de condicionamento físico no broncoespasmo induzido pelo exerć́cio em mulheres obesas. Rev Bras Med Esporte. 2009;15(3):190-4. DOI

12. Vanhelst J, Fardy PS, Salleron J, Béghin L. The six-minute walk test in obese youth: reproducibility, validity, and prediction equation to assess aerobic power. Disabil Rehabil. 2013;35(6):479-82. DOI

13. Ferreira MS, Mendes RT, Marson FAL, Zambon MP, Paschoal IA, Toro AADC, et al. The relationship between physical functional capacity and lung function in obese children and adolescents. BMC Pulm Med. 2014;14:199. DOI

14. Negreiros A, Padula RS, Bernardes RAB, Moraes MV, Pires RS, Chiavegato LD. Predictive validity analysis of six reference equationsfor the 6-minute walk test in healthy Brazilian men: across-sectional study. Braz J Phys Ther. 2017;21(5): 350-6. DOI

15. Soares KKD, Gomes ELFD, Beani Jr A, Oliveira LVF, Sampaio LMM, Costa D. Avaliação do desempenho físico e funcional respiratório em obesos. Fisioter Mov. 2011;24(4): 697704. DOI

16. Silva CB, Gonçalves KD, Silveira JM, Reis GR, Ueda TK. Comparação da distância percorrida em três modalidades do teste de caminhada de seis minutos com equações preditivas. ASSOBRAFIR Cienc. 2012;3(3):19-29. Full text link

17. Leiner GC, Abramowitz S, Small MJ, Stenby VB, Lewis WA. Expiratory peak flow rate. Standard values for normal subjects. Use as a clinical test of ventilatory function. Am Rev Respir Dis. 1963;88:644-51. Full text link

18. Enright PL, Sherrill DL. Reference equations for the sixminute walk in healthy adults. Am J Respir Crit Care Med 1998;158(5 Pt 1):1384-7. DOI
19. Rowe A, Hernandez P, Kuhle S, Kirkland S. The association between anthropometric measures and lung function in a population-based study of Canadian adults. Respir Med. 2017;131:199-204. DOI

20. Zakaria R, Harif N , Al-Rahbi B, Aziz CBA, Ahmad AH. Gender differences and obesity influence on pulmonary function parameters. Oman Med J. 2019;34(1):44-8. DOI

21. Wang S, Sun X, Hsia TC, Lin X, Li M. The effects of body mass index on spirometry tests among adults in Xi'an, China. Medicine (Beltimore). 2017:96(15):e6596. DOI

22. Gundogdu Z, Eryilmaz N. Correlation between peak flow and body mass index in obese and non-obese children in Kocaeli, Turkey. Prim Care Respir J. 2011;20(4):403-6. DOI

23. Al Ghobain M. The effect of obesity on spirometry tests among healthy non-smoking adults. BMC Pulm Med. 2012;12:10. DOI

24. Alves EC, Silva DD, Oliveira LHS. Análise comparativa do pico de fluxo expiratório de universitários saudáveis, obesos e tabagistas. Rev Eletr Acervo Saude. 2014;1:63-9. Full text link

25. Retory Y, Picciotto C, Niedzialkowski P, Petitjean M, Bonay M. Body mass index-dependent ventilator parameters from respiratory inductive plethysmography during 6-minute walk test. Respir Care. 2016;61(4):521-8. DOI

26. Bautista J, Ehsan M, Normandin E, Zuwallack R, Lahiri B. Physiologic responses during the six minute walk test in obese and non-obese COPD patients. Respir Med. 2011;105(8):118994. DOI

27. Santarém GCF, Cleva $R$, Santo $M A$, Bernhard $A B$, Gadducci AV, Greve JMA, et al. Correlation between body composition and walking capacity in severe obesity. PloS One. 2015;10(6):e0130268. DOI

28. Gontijo PL, Lima TP, Costa TR, Reis EP, Cardoso FPF, Cavalcanti Neto FF. Correlação da espirometria com o teste de caminhada de seis minutos em eutróficos e obesos. Rev Assoc Med Bras. 2011;57(4):387-93. DOI

29. Manzano RM, Kishi MS, Silva MCM, Biazon RF, Ambrozin ARP. Comparação das variáveis hemodinâmicas durante o teste de caminhada de seis minutos e o teste de escada em adultos saudáveis. Ter Man. 2012;10(49):311-6. Full text link 
30. Gondoni LA, Nibbio F, Caetani G, Augello G, Titon AM. What are we measuring? Considerations on subjective ratings of perceived exertion in obese patients for exercise prescription in cardiac rehabilitation programs. Int J Cardiol. 2010;140(2):236-8. DOI

31. Antonio TTD, Assis MR. Duplo-produto e variação da frequência cardíaca após esforço isocinético em adultos e idosos. Rev Bras Med Esporte. 2017;23(5):394-8. DOI
32. Trevizani GA, Benchimol-Barbosa PR, Nadal J. Effects of age and aerobic fitness on heart rate recovery in adult men. Arq Bras Cardiol. 2012;99(3):802-10. DOI

33. Beydon N, Davis SD, Lombardi E, Allen JL, Arets HGM, Aurora $\mathrm{P}$, et al. An official American Thoracic Society/ European Respiratory Society statement: pulmonary function testing in preschool children. Am J Respir Crit Care Med. 2007;175(12):1304-45. DOI 